\title{
Effect of waterlogging stress on the growth, development and symptomatology of cape gooseberry (Physalis peruviana L.) plants
}

\author{
Fernando Aldana ${ }^{1}$, Pedro Nel García ${ }^{1}$, Gerhard Fischer ${ }^{1, *}$ \\ ${ }^{1}$ Department of Agronomy, Faculty of Agricultural Sciences, Universidad Nacional de Colombia, Bogotá, Colombia
}

\begin{abstract}
Climate change has altered normal rainfall cycles; causing the flooding of arable land and, thus, affecting agricultural production in Colombia. Two-month-old cape gooseberry plants, propagated by seeds, were subjected to different durations of continuous waterlogging in a greenhouse: 0, 2, 4, 6 and 8 days, with evaluations up to 50 days. The plants were placed in ditches covered with polyethylene and filled with water up to $5 \mathrm{~cm}$ above the substrate surface of the pots. The parameters evaluated were: plant height, leaf area, stem diameter, dry weight of the aerial part, root and reproductive organs, and general symptoms following a wilting scale. The 6 and 8-day-waterlogged plants were the most affected by the flooding conditions, presenting the lowest values for all the measured variables. Due to the oxygen stress in the root zone, the plants showed yellowing, epinasty, necrosis and abscission of the leaves, more so in the 8-day-waterlogged plants.
\end{abstract}

Key words: Hypoxia, leaf area, dry weight, symptoms.

Efecto del estrés por anegamiento sobre el crecimiento, desarrollo y sintomatología de plantas de uchuva (Physalis peruviana L.)

\begin{abstract}
Resumen
El cambio climático ha alterado el ciclo normal de las lluvias, inundando así las tierras arables y afectando la producción agrícola en Colombia. Plantas de uchuva, de 2 meses de edad, y propagadas por semilla, fueron sometidas bajo invernadero a diferentes duraciones de anegamiento continuo: 0, 2, 4, 6 y 8 días y evaluaciones hasta 50 días. Las plantas se colocaron en zanjas cubiertas con polietileno que se llenaron con agua hasta $5 \mathrm{~cm}$ por encima de la superficie del sustrato contenido en las macetas. Los parámetros evaluados fueron: altura de planta, área foliar, diámetro del tallo, pesos secos de parte aérea, raíz y órganos reproductivos y escala de síntomas generales de marchitamiento. Las plantas anegadas durante 6 y 8 días presentaron los valores más bajos para todas las variables evaluadas. Debido al estrés por falta de oxígeno en la rizósfera las plantas mostraron amarillamiento, epinastia, necrosis y abscisión de hojas, sobre todo en las de 8 días anegadas.
\end{abstract}

Palabras clave: hipoxia, área foliar, peso seco, síntomas.

\section{Introducción}

Abiotic stress from waterlogging and flooding affects large areas of the world (Martínez-Alcántara et al., 2012). In Colombia, since 2007, climate change has caused heavy rains even in the "summer" periods" and the "La Niña Phenomenon" has brought about major flooding, affecting up to 19 departments with large-scale decreases in agricultural production, especially near rivers and on flat lands, while, globally, floods have increased $7.4 \%$ per year on average for the last 10 years (Agudelo, 2009).

Waterlogging of the soil and deeper submergence cause stress in plants, characterized by Jackson and Colmer (2005) as one of the major abiotic constraints on growth, development, distribution of species and productivity of agricultural crops. This stress is caused by reduced $\mathrm{O}_{2}$ availability for plant cells, induced by waterlogging or soil compactation (BaileySerres and Voesenek, 2008). Flood water fills soil pores, thereby reducing oxygen availability, and the diffusion of dissolved $\mathrm{O}_{2}$ in stagnant water is so slow that only a thin layer of soil near the surface contains oxygen (Taiz and Zeiger, 2010).

\footnotetext{
*Correspondencia:

Gerhard Fischer, gerfischer@gmail.com, gfischer@unal.edu.co

Recibido: 9 de septiembre de 2014

Aceptado: 16 de diciembre de 2014
} 
Prolonged flooding conditions may result in crop losses $>10 \%$ (Bange et al., 2004), $>40 \%$ in severe cases (Hodgson and Chan, 1982). As a result of the disturbance of the physiological functioning of plants, the vegetative and reproductive growth is negatively affected (Gibbs and Greenway, 2003). Das (2012) reported large differences in plant tolerance to flooding and insufficient aeration of root media among herbaceous species.

The first symptom of flooding damage is stomatal closure, which affects not only gas exchange, but also decreases the passive absorption of water, which is also negatively influenced by anaerobic conditions in the rhizosphere (Kozlowski and Pallardy, 1997). A decrease in transpiration leads to leaf wilting and early senescence; finally resulting in foliar abscission (Ashraf, 2012; Kozlowski and Pallardy, 1997).

The respiration of roots in waterlogged soils that are poorly (hypoxia) or not at all aerated (anoxia), in which gas diffusion is severely inhibited (Armstrong et al., 1994), changes from aerobic to anaerobic conditions, being very detrimental to the development of plants.

In soils with a severely reduced $\mathrm{O}_{2}$ partial pressure, the availability of nutrients for plants is strongly decreased (Blom and Voesenek, 1996). When the availability of oxygen in the soil is reduced, anaerobic microorganisms dominate, creating strongly reducing conditions in the rhizosphere in which $\mathrm{Fe}^{2+}$, $\mathrm{Mn}^{2+}, \mathrm{H}_{2} \mathrm{~S}$, sulfides, lactic acid, and butyric acid, among others, increase to toxic concentrations (Larcher, 2003).

The cape gooseberry (Physalis peruviana L., Solanaceae), an Andean fruit species that has gained immense importance in Colombia due to its potential for export as fresh fruit (Fischer et al., 2007), is easily adapted to a wide range of ecological conditions and grows as a wild and semi-wild plant from Chile to Colombia (Fischer, 2000). In Colombia, commercial crops are found between 1,800 and 2,800 m a.s.l., with an average temperature between 13 and $16^{\circ} \mathrm{C}$, well-distributed rainfall from 1,000 to $1,800 \mathrm{~mm}$ per year, and a requirement for an average relative humidity from 70 to $80 \%$ (Fischer and Miranda, 2012).

The cape gooseberry is an herbaceous plant with a large vegetative development, achieving a height of 1 to $1.5 \mathrm{~m}$ without trellis (Fischer and Miranda, 2012). Most roots are fibrous and are between 10 to $15 \mathrm{~cm}$ in depth (Fischer, 2000); the branched root system extends up to a radius of $60 \mathrm{~cm}$ (Galindo and Pardo, 2010) with an effective rooting depth of $60 \mathrm{~cm}$ (Angulo, 2005); while the formation of adventitious roots at the lower nodes of vegetative basal stems can be observed (Galindo and Pardo, 2010). The cape gooseberry thrives well in soils with a granular structure that allows for good aeration and drainage of the roots (Angulo, 2005), with water tables deeper than $1 \mathrm{~m}$ (Fischer and Miranda, 2012).
Six-day-waterlogging affected the potted cape gooseberry plants through a reduction in root growth, leaf area and, consequently, a diminished biomass production (Villareal, 2014). In another solanaceous plant, the tomato, waterlogging reduced stem growth, leaf area, fruit set and fruit yield (Lopez and Rosario, 1983). Ezin (2010) observed leaf yellowing (senescence), wilting and adventitious root formation in 8-day-flooded tomato genotypes as symptoms of tolerance to flooding.

Because the technological cultivation of the cape gooseberry relies mostly on empirical knowledge (Fischer and Miranda, 2012) and the damage caused by waterlogging and flooding in Colombia in recent years is high, the objective of this research was to study the effect of short-term waterlogging, 2 to 8 days, on the growth and development of this plant species.

\section{Materials and methods}

The research was conducted at the Faculty of Agricultural Sciences, National University of Colombia, Bogota, located at 2,556 m. a.s.l., in a plastic greenhouse with an average temperature of $15.3^{\circ} \mathrm{C}$ and relative humidity of $64 \%$. The plant material used consisted of cape gooseberry seedlings (Physalis peruviana L.), ecotype 'Colombia' with an age of 30 days after emergence (dae). These seedlings were left in an adaptation phase of 1 month in the greenhouse, still in the juvenile growing phase, before being transplanted into $10 \mathrm{~L}$ plastic pots (22 cm diameter by $20 \mathrm{~cm}$ high), using as substrate the greenhouse soil ( $\mathrm{pH} 5.78$; $\mathrm{CO} 4.47 \%$; N 0.39\%; Ca 9.6, Mg 2.16, Na 0.21, K 182, Al 0.09, H 0.07, and CIC 22.4 meq/100 g; P 264.1, Mn 11.15, Zn 21.2, Fe 713, Cu 1.90 , and B $0.55 \mathrm{mg} \mathrm{kg}^{-1}$; with a loam texture), disinfected by solarization. To simulate the conditions of waterlogging on the plants, four ditches in the soil, $30 \mathrm{~cm}$ deep, $30 \mathrm{~cm}$ wide and $7 \mathrm{~m}$ long, were used, which were covered with caliber-6 black polyethylene plastic, these ditches were filled with potable water from the local aqueduct to a depth of $25 \mathrm{~cm}$.

When the plants reached an age of 90 dae, the waterlogging treatments started, placing the pots in the water filled ditches, 15 plants per ditch, for 2, 4, 6 and 8 days. The control plants were placed next to the corresponding ditch without dipping into the water. Triple 15 (NPK) was applied at a dose of $5 \mathrm{~g}$ per 1-month dae plant, and, at 2-months dae a complete fertilizer was applied (mg/L per plant): N 100.0, P 25.0, K 80.0, Ca 50.0, Mg 40.0, S 28.0, Fe 6.0, Mn 3.0, Cu 0.7; Zn 1.5, B 0.3.

\section{Experimental design}

The experimental design consisted of randomized complete blocks: the four blocks corresponded to the flooded ditches; and the five treatments were: $0,2,4,6$ and $8 \mathrm{~d}$ of waterlogging. The experimental units (or replications) were the plants growing in pots, 15 per block and 12 per treatment, i.e. a total of 60 plants for the whole experiment. 


\section{Measurements of growth and development}

Before starting the treatments, an initial measurement (0 days) of plant height and leaf area was taken. One week after finishing the waterlogging treatments, plant height and leaf area were recorded weekly, as well as the number of reproductive units (flower buds, flowers and fruits). In addition to these measurements, a modified scale of Yeboah et al. (2008) with values of 0-5 was used to assess weekly symptoms generated by the waterlogging stress. Also, a photographic record of five plants, representing the different durations of waterlogging, was kept weekly.

At the end of the trial (50 days after the waterlogging treatments started), the diameter was recorded at the base of the stem ( $3 \mathrm{~cm}$ above the root collar) and the dry weights of the aerial parts (stems and leaves), the root system, and the reproductive parts (flower buds, flowers and fruits) were determined. For this, the samples were placed in an oven at a temperature of $70^{\circ} \mathrm{C}$ until the weight remained constant (3 days); the weights were measured with an electronic balance with an accuracy of $0.01 \mathrm{~g}$.

To calculate the leaf area of the plants, several leaf samples were taken and by means of a scanner, their silhouettes were digitized using the program ImageJ, version 1.45, and the leaf area was calculated.

\section{Statistical analysis}

The collected data were subjected to variance analysis using the Statistical Analysis System (SAS version 9.1) to determine differences among the treatments. The means were compared using the Tukey HSD (honestly significant difference) test at $P \leq 0.05$.

\section{Results and discussion}

\section{Plant height}

Treatments of 0 and 2 days of waterlogging showed a very similar plant height without significant differences $(P>0.05)$, while the 4-day-waterlogged plants decreased growth at 15 and $22 \mathrm{~d}(P \leq 0.05)$, with subsequent recovery (Table 1$)$. In the 6-day-waterlogged cape gooseberry, the stem elongation was nearly paralyzed and, in the 8-day-waterlogged plants, it decreased with the onset of plant death from day 25 after the waterlogging treatments started.

The significantly larger longitudinal growth of the 0 to 4 days waterlogged plants as compared to the 6 to 8 days waterlogged plants may be related to the sufficient supply of the phytohormones cytokinins and gibberellins, which are synthesized in the root system, which was not affected by the lack of oxygen in these treatments, because Bradford and Yang (1981) observed a reduction of these hormones in xylem sap of flooded tomato plants. Furthermore, according to Shiu et al. (1998), the dramatic reduction in the longitudinal growth of the 6 to 8 days treated plants may have been influenced by ethylene, since, under conditions of hypoxia, ethylene biosynthesis is increased, due to the synthesis of 1-aminocyclopropane-1-carboxylic acid (ACC) in the roots and its fast transport to the stem. Once in the leaves, ACC is converted by ACC oxidase to ethylene, which is associated with the inhibition of stem growth, leaf wilting and curling, typical plant responses to flooded conditions (Lorbiecke and Sauter, 1999). On the other hand, Jordan and Casaretto (2006) attributed this effect to an inhibitory action of abscisic acid (ABA), which is best expressed in terms of lack of oxygen; ABA is able to inhibit stem elongation rather than roots. On the other hand, waterlogging reduces the absorption of nutrients such as $\mathrm{N}, \mathrm{P}$ and $\mathrm{K}$ (Kozlowski and Pallardy, 1997), among which, in the case of the cape gooseberry, $\mathrm{N}$ deficiency has the greatest effect on longitudinal stem growth (Martínez et al., 2009). The same reduction in stem length was observed by Baracaldo $\boldsymbol{e t}$ al. (2014) in 2-month-old chonto tomato plants waterlogged for 4,8 and 12 days, from 16 days after treatment initiation.

\section{Leaf area}

As in the case of plant height, the cape gooseberry waterlogged for 0,2 and 4 days showed no significant differences in leaf area during the evaluation period (Table 2). The 6-day-waterlogged plants developed a significantly lower

Table 1. Plant height of cape gooseberry (Physalis peruviana L.) subjected at an age of 2 months to waterlogging of different durations.

\begin{tabular}{cccccccc}
\hline \multirow{2}{*}{$\begin{array}{c}\text { Duration of } \\
\text { waterlogging (days) }\end{array}$} & \multicolumn{7}{c}{ Plant height (cm) } \\
\cline { 2 - 7 } & $\mathbf{0}$ & $\mathbf{1 5}$ & $\mathbf{2 2}$ & $\mathbf{2 9}$ & $\mathbf{3 6}$ & $\mathbf{4 3}$ & $\mathbf{5 0}$ \\
\cline { 2 - 7 } & $56.92 \mathrm{a}$ & $71.67 \mathrm{a}$ & $79.50 \mathrm{a}$ & $88.75 \mathrm{a}$ & $94.13 \mathrm{a}$ & $97.33 \mathrm{a}$ & $105.17 \mathrm{a}$ \\
\hline 0 & $56.92 \mathrm{a}$ & $71.25 \mathrm{a}$ & $78.67 \mathrm{a}$ & $89.50 \mathrm{a}$ & $95.17 \mathrm{a}$ & $96.92 \mathrm{a}$ & $107.92 \mathrm{a}$ \\
\hline 2 & $56.92 \mathrm{a}$ & $62.25 \mathrm{~b}$ & $65.17 \mathrm{~b}$ & $72.83 \mathrm{ab}$ & $76.84 \mathrm{ab}$ & $80.75 \mathrm{ab}$ & $89.67 \mathrm{ab}$ \\
\hline 6 & $56.92 \mathrm{a}$ & $57.42 \mathrm{~b}$ & $58.42 \mathrm{bc}$ & $58.25 \mathrm{~b}$ & $58.20 \mathrm{~b}$ & $58.33 \mathrm{~b}$ & $61.45 \mathrm{bc}$ \\
\hline 8 & $56.92 \mathrm{a}$ & $53.75 \mathrm{~b}$ & $52.25 \mathrm{c}$ & $26.92 \mathrm{c}$ & $28.15 \mathrm{c}$ & $31.08 \mathrm{c}$ & $34.17 \mathrm{c}$ \\
\hline
\end{tabular}

Means with different letters in the same column indicate a significant difference according to Tukey's test $(P \leq 0.05)$. 
Table 2. Leaf area of the cape gooseberry (Physalis peruviana L.) plants subjected at an age of 2 months to waterlogging of different durations.

\begin{tabular}{|c|c|c|c|c|c|c|c|}
\hline \multirow{3}{*}{$\begin{array}{c}\text { Duration of } \\
\text { waterlogging (days) }\end{array}$} & \multicolumn{7}{|c|}{ Leaf area $\left(\mathrm{cm}^{2}\right)$} \\
\hline & \multicolumn{7}{|c|}{ Days after waterlogging started } \\
\hline & $\mathbf{0}$ & 15 & 22 & 29 & 36 & 43 & 50 \\
\hline 0 & 2059.3 a & 2924.9 a & 3016.3 a & 3433.1 a & 3681.8 a & 3786.5 a & 3828.4 a \\
\hline 2 & 2059.3 a & $2486.7 \mathrm{ab}$ & $2542.9 \mathrm{ab}$ & $2820.7 \mathrm{ab}$ & $2996.5 \mathrm{ab}$ & $3098.0 \mathrm{ab}$ & $3179.8 \mathrm{ab}$ \\
\hline 4 & 2059.3 a & $2026.1 \mathrm{ab}$ & $2055.0 \mathrm{abc}$ & $2317.9 \mathrm{ab}$ & $2725.8 \mathrm{ab}$ & $2996.1 \mathrm{ab}$ & $3149.6 \mathrm{ab}$ \\
\hline 6 & 2059.3 a & $1891.0 \mathrm{ab}$ & 1709.7 bc & $1725.8 \mathrm{bc}$ & $1748.7 \mathrm{bc}$ & 1745.6 c & $1720.3 \mathrm{bc}$ \\
\hline 8 & 2059.3 a & $1512.7 \mathrm{~b}$ & $1015.8 \mathrm{c}$ & 879.7 c & 896.5 c & 1014.2 c & $1284.0 \mathrm{c}$ \\
\hline
\end{tabular}

Means with different letters in the same column indicate a significant difference according to Tukey's test $(P \leq 0.05)$.

leaf area $(P \leq 0.05)$ than the control plants from day 22 on, but without difference $(P>0.05)$ with those waterlogged for 8 days, which had marked leaf area reductions. At the end of the trial, the waterlogged plants, between 0 and $4 \mathrm{~d}$, had more than twice the number of leaves, as compared with the 6 and 8 days treatments (data not shown).

Also Casierra-Posada and Vargas (2007) found that flooded strawberry plants reached only $36.8 \%$ of the leaf area of plants kept under normal soil humidity conditions. These authors attributed this finding, among other reasons, to an inhibition of the expansion of the leaf due to the reduction of the extensibility of the cell walls, a determinant growth factor under hypoxic root conditions (Smit et al., 1989).

The marked leaf area decrease in the cape gooseberry plants waterlogged for 6 and 8 days can be attributed to a reduction in the photosynthetic rate, as observed in solanaceous species such as the tomato (Walter et al., 2004), due to stomatal closure (Kozlowski and Pallardy, 1997) and the adverse effects of this stress on the photosynthetic capacity (Bradford and Yang, 1981), which Kozlowski and Pallardy (1997) associated with changes in enzyme carboxylation, reduced chlorophyll content and lower leaf area as caused by an inhibited formation, expansion, injury, and abscission of leaves.

The decrease in the rate of leaf $\mathrm{CO}_{2}$ exchange under waterlogging stress conditions was also reported by Davies and Flore (1986) in the blueberry (Vaccinium ashei), accompanied by a reduced stomatal conductivity, and Jackson (1990) in the tomato, observing a stomatal closure with increasing levels of abscisic acid in the leaves. In studies with flooded tomatoes that applied chlorophyll fluorescence, Ezin et al. (2010) and Kläring and Zude (2009) observed that the reduction in photosynthetic rates is related to limitations in the PSII reaction center.

Six- and 8-day-waterlogged plants showed abscission of the lower leaves (Das, 2012; Kozlowski and Pallardy, 1997), which were accentuated in the 8-day-waterlogged plants from day 22 of our experiment (Tab. 2).

\section{Diameter of the stem base}

At 50 days of the evaluation, the diameter of the stem base did not differ $(P>0.05)$ in the 0 - to 4-day-submerged plants, while in the plants waterlogged for 6 days, as compared with those of 2 days and the control, the stem diameter was significantly reduced (Table 3). The stem of the 8-day-stressed plants was significantly thinner $(P \leq 0.05)$ as compared with the 4-day and less waterlogged plants.

The lower stem diameter growth of the 6- and 8-daywaterlogged cape gooseberry indicates that these plants had a reduced rate of photosynthesis (Kozlowski and Pallardy, 1997) and, consequently, a lower translocation of photoassimilates to this organ as compared with the shorter stress time, considering that the cape gooseberry accumulates the second largest amount of reserve sugars (starch and sucrose), after the roots, at the base of the vegetative stem (unpublished data by G. Fischer). Furthermore, we observed that the optimal radial stem growth of the long-time-waterlogged plants was affected by the onset of fungal rot, confirming the studies of Villareal (2014) that showed that a waterlogging of 6 days increased the susceptibility of cape gooseberry to Fusarium oxysporum.

Table 3. Diameter of the stem base of cape gooseberry (Physalis peruviana L.) plants subjected at an age of 2 months to waterlogging of different durations 50 days after treatments started.

\begin{tabular}{cc}
\hline Duration of waterlogging (days) & Diameter of the stem base $(\mathbf{m m})$ \\
\hline 0 & $19.56 \mathrm{a}$ \\
\hline 2 & $19.32 \mathrm{a}$ \\
\hline 4 & $16.68 \mathrm{ab}$ \\
\hline 6 & $11.76 \mathrm{bc}$ \\
\hline 8 & $6.60 \mathrm{c}$ \\
\hline
\end{tabular}

Means with different letters indicate a significant difference according to Tukey's test $(P \leq 0.05)$. 


\section{Number of reproductive organs}

With an increased number of waterlogging days, the number of flowers and fruits constantly decreased, while the treatments of 0 to 2 days developed the most reproductive organs (Table 4). The treatments of 6 and 8-day-waterlogging, from day 22, developed significantly less reproductive organs as compared to the shorter treatments.

Kozlowski and Pallardy (1997) reported that, in flooded conditions, the formation of flower buds, anthesis, formation and growth of fruit in non-waterlogging-tolerant plants are inhibited. Thus, the flooded plants between 4 and 8 days showed a delay in growth and development as compared with a shorter stress time (Tables 1 and 2), so the onset of flowering was delayed, considering that the cape gooseberry produces

Table 4. Number of flower buds, flowers and fruits of cape gooseberry (Physalis peruviana L.), subjected at an age of 2 months to waterlogging of different durations.

\begin{tabular}{|c|c|c|c|c|c|c|}
\hline \multirow{3}{*}{$\begin{array}{l}\text { Days after } \\
\text { waterlogging } \\
\text { started }\end{array}$} & & \multicolumn{5}{|c|}{ Number of reproductive units } \\
\hline & & \multicolumn{5}{|c|}{ Duration of waterlogging (days) } \\
\hline & & $\mathbf{0}$ & 2 & 4 & 6 & 8 \\
\hline \multirow{4}{*}{15} & Flower buds & $12.1 \mathrm{a}$ & $11.6 \mathrm{ab}$ & $9.0 \mathrm{bc}$ & $7.4 \mathrm{c}$ & $6.7 \mathrm{c}$ \\
\hline & Flowers & $2.3 \mathrm{a}$ & $2.2 \mathrm{ab}$ & $1.6 \mathrm{ab}$ & $1.0 \mathrm{ab}$ & $0.8 \mathrm{~b}$ \\
\hline & Fruits & $0.3 \mathrm{a}$ & $0.8 \mathrm{a}$ & $0.3 \mathrm{a}$ & $0.2 \mathrm{a}$ & $0.2 \mathrm{a}$ \\
\hline & Total & 14.7 a & 14.5 a & $10.8 \mathrm{ab}$ & $8.6 \mathrm{~b}$ & $7.7 \mathrm{~b}$ \\
\hline \multirow{4}{*}{22} & Flower buds & $22.6 \mathrm{a}$ & $21.3 \mathrm{a}$ & $14.3 \mathrm{~b}$ & 10.9 bc & $9.3 \mathrm{c}$ \\
\hline & Flowers & $4.2 \mathrm{a}$ & $4.3 \mathrm{a}$ & $3.1 \mathrm{ab}$ & $2.0 \mathrm{~b}$ & $1.6 \mathrm{~b}$ \\
\hline & Fruits & $2.8 \mathrm{ab}$ & $3.0 \mathrm{a}$ & $1.8 \mathrm{ab}$ & $0.8 \mathrm{~b}$ & $0.8 \mathrm{~b}$ \\
\hline & Total & 29.5 a & 28.5 a & $19.2 \mathrm{~b}$ & 13.7 bc & $11.7 \mathrm{c}$ \\
\hline \multirow{4}{*}{29} & Flower buds & 26.8 a & 24.6 a & $15.6 \mathrm{~b}$ & 10.8 bc & $4.8 \mathrm{c}$ \\
\hline & Flowers & $5.3 \mathrm{a}$ & $4.7 \mathrm{a}$ & $3.6 \mathrm{a}$ & $1.3 \mathrm{~b}$ & $1.3 \mathrm{~b}$ \\
\hline & Fruits & $6.8 \mathrm{ab}$ & $8.5 \mathrm{a}$ & $6.0 \mathrm{abc}$ & 3.6 bc & $2.3 \mathrm{c}$ \\
\hline & Total & 38.9 a & 37.8 a & $25.2 \mathrm{~b}$ & 15.6 bc & $8.4 \mathrm{c}$ \\
\hline \multirow{4}{*}{36} & Flower buds & $33.0 \mathrm{a}$ & $27.5 \mathrm{ab}$ & $21.8 \mathrm{ab}$ & $12 \mathrm{c}$ & $6.3 \mathrm{c}$ \\
\hline & Flowers & $7.0 \mathrm{a}$ & $6.5 \mathrm{ab}$ & $4.4 \mathrm{ab}$ & $2.4 \mathrm{bc}$ & $1.7 \mathrm{c}$ \\
\hline & Fruits & $25.0 \mathrm{a}$ & $21.0 \mathrm{a}$ & $14.8 \mathrm{~b}$ & $8.3 \mathrm{bc}$ & $3.8 \mathrm{c}$ \\
\hline & Total & $65.0 \mathrm{a}$ & $55.0 \mathrm{a}$ & $41 \mathrm{~b}$ & $22.7 \mathrm{c}$ & $11.8 \mathrm{c}$ \\
\hline \multirow{4}{*}{43} & Flower buds & 39.0 a & $32.4 \mathrm{a}$ & $27.4 \mathrm{~b}$ & 13.9 bc & $7.9 \mathrm{c}$ \\
\hline & Flowers & $9.0 \mathrm{a}$ & $8.3 \mathrm{ab}$ & $5.0 \mathrm{~b}$ & 3.5 bc & $2.0 \mathrm{c}$ \\
\hline & Fruits & $36.1 \mathrm{a}$ & $33.0 \mathrm{a}$ & $20.3 \mathrm{~b}$ & $12.6 \mathrm{bc}$ & $6.4 \mathrm{c}$ \\
\hline & Total & 84.0 a & 73.7 a & $52.7 \mathrm{~b}$ & $30 \mathrm{bc}$ & $16.3 \mathrm{c}$ \\
\hline \multirow{4}{*}{50} & Flower buds & 43.9 a & 39.0 a & $31.2 \mathrm{a}$ & $15.8 \mathrm{~b}$ & $9.8 \mathrm{~b}$ \\
\hline & Flowers & $11.3 \mathrm{a}$ & $10.1 \mathrm{ab}$ & $6.3 \mathrm{bc}$ & $3.4 \mathrm{c}$ & $2.2 \mathrm{c}$ \\
\hline & Fruits & $43.1 \mathrm{a}$ & $40.2 \mathrm{a}$ & $25.5 \mathrm{~b}$ & $13.0 \mathrm{bc}$ & $7.9 \mathrm{c}$ \\
\hline & Total & 98.3 a & $89.3 \mathrm{ab}$ & $63 \mathrm{bc}$ & $32.3 \mathrm{c}$ & $19.8 \mathrm{c}$ \\
\hline
\end{tabular}

Means with different letters in the same row indicate a significant difference according to Tukey's test $(P \leq 0.05)$. one flower at each node of the reproductive shoots (Fischer, 2000). Also, Ezin et al. (2010) found a reduction in the number of flowers and fruits and in the fruit size and weight in the tomato, attributing these results to the inhibition of photosynthesis and the adverse effects of flooding conditions.

Reproductive processes require a lot of energy (Fischer $\boldsymbol{e t}$ al., 2012), which may be deficient in plants waterlogged between 4 and 8 days due to a lack of oxygen and consequent hormonal imbalance (Bradford and Yang, 1981). In addition, the low production of photoassimilates, negatively affected, among other factors, by the reduced leaf area (Table 2), stomatal closure and wilted leaves (Figure 1), may have contributed to the early abscission of flowers and fruits (Tadeo and Gómez-Cadenas, 2008).

\section{Dry weight of organs}

Nevertheless, as for the treatments of 0 and 2 days, no significant differences $(P>0.05)$ in terms of dry weight (DW) of the plant organs were observed; the 4-day-waterlogging significantly decreased $(P \leq 0.05)$ plant biomass (Table 5$)$, with drastic reductions when the plants were waterlogged for 8 days. This longer duration of stress reduced the total plant DW by $66.51 \%$, while the stem and leaves had only $40.74 \%$ DW, roots $24.41 \%$ DW, and reproductive organs only $17.01 \%$ of DW as compared to the non-waterlogged plants.

This high negative effect on the biomass production of the reproductive plant organs, was supposed to be due to the lack of energy sources (ATP) (Bailey-Serres and Voesenek, 2008) and hormonal imbalance (Bradford and Yang, 1981) for the induction of metabolic processes. The drastic reduction in root biomass means that excess water limits the growth and functioning of this organ (Das, 2012). This type of stress displaces air from the non-capillary pore space of soils, causing oxygen deficiency and, consequently, the death of many roots (Armstrong and Drew, 2002). Also, Bennet

Table 5. Dry weight of stems and leaves, reproductive organs (floral buds, flowers and fruits) and roots of cape gooseberry (Physalis peruviana L.) subjected at an age of 2 months to waterlogging of different durations at $50 \mathrm{~d}$ after waterlogging started.

\begin{tabular}{ccccc}
\hline $\begin{array}{c}\text { Duration of } \\
\text { waterlogging } \\
\text { (days) }\end{array}$ & \multicolumn{4}{c}{ Dry weight (g) } \\
\cline { 2 - 5 } & $\begin{array}{c}\text { Stems and } \\
\text { leaves }\end{array}$ & $\begin{array}{c}\text { Reproductive } \\
\text { organs }\end{array}$ & Roots & Total \\
\hline 0 & $52.093 \mathrm{a}$ & $7.818 \mathrm{a}$ & $27.437 \mathrm{a}$ & $87.347 \mathrm{a}$ \\
\hline 2 & $49.788 \mathrm{a}$ & $7.503 \mathrm{a}$ & $26.205 \mathrm{a}$ & $83.497 \mathrm{a}$ \\
\hline 4 & $35.543 \mathrm{~b}$ & $4.308 \mathrm{~b}$ & $12.983 \mathrm{~b}$ & $52.834 \mathrm{~b}$ \\
\hline 6 & $26.591 \mathrm{c}$ & $2.493 \mathrm{bc}$ & $10.013 \mathrm{~b}$ & $39.097 \mathrm{bc}$ \\
\hline 8 & $21.226 \mathrm{c}$ & $1.330 \mathrm{c}$ & $6.698 \mathrm{~b}$ & $29.254 \mathrm{c}$ \\
\hline
\end{tabular}

Means with different letters in the same column indicate a significant difference according to Tukey's test $(P \leq 0.05)$. 
(2003) stated that anoxic conditions prevent root growth and send signals to the aerial part of the plant to reduce shoot growth and, finally, plant productivity. An increased proportion of root dry mass (DM) in waterlogged plants was not observed (8-day and 6-day stressed plants accumulated only 22.98 and $25.61 \%$ of their total DM in roots, as compared to the $31.41 \%$ of the control plants); however, Casierra-Posada and Gómez (2008) reported an adaptation to the lack of oxygen in the root medium.

The decrease in longitudinal growth (Table 1) and leaf area (Table 2) affected plant biomass production of the stems and leaves and, consequently, the production of photoassimilates for these organs as the foliar apparatus is highly affected by waterlogging (stomatal closure, wilting, burn and abscission of leaves; Kozlowzki and Pallardy, 1997; Das, 2012). The reduction of total DW indicates that photosynthetic capacity is strongly inhibited under conditions of waterlogging (CasierraPosada and Gómez, 2008), and that the cape gooseberry has little tolerance to this kind of stress.

\section{General stress symptoms due to waterlogging}

According to the stress scale of Yeboah et al. (2008), the 0 - and 2-day-waterlogged cape gooseberry plants did not differ on the symptoms scale during the assessment time (Table 6). The 4-day-waterlogged plants showed signs of stress, such as crinkling and foliar turgor loss, after 15 days, but recovered by the end of the experiment (Figure 1, Table $6)$. The re-establishment of normoxia-like plant appearance and turgency 43 days after drainage (Table 6) indicates the plant's ability to cope with hypoxia if normoxic conditions are adjusted in a suitable amount of time (Kläring and Zude, 2009).

The cape gooseberries waterlogged for 6 days, and especially those for 8 days, showed the most severe symptoms of stress in the test with $75-100 \%$ curled leaves (without their margins connecting) (Figure 1). Curling, or epinasty, is caused by the greater growth of the adaxial portion rather than the abaxial portion of the leaf, thereby minimizing the interception of light and transpiration loss (Armstrong and Drew, 2002).
This reaction is found within the chain of symptoms caused by hypoxia in the rhizosphere, which directly affects the roots and indirectly affects the stem, finally causing the cessation of growth, epinasty and wilting of the leaves, with stomatal closure (inhibiting photosynthesis and respiration) as well as senescence and abscission (Tadeo and Gómez-Cadenas, 2008). The epinasty of leaves takes place as a result of high concentration of ethylene in ethylene responsive cells of leaves (the precursor of ethylene, ACC, induced by hypoxia conditions in roots, is transported from xylem sap to leaves). Also, an oxygen shortage in roots stimulates the production of abscisic acid (ABA) and the movement of ABA to leaves can account for the stomatal closure response (Dwivedi and Dwivedi, 2012). In the pea (Pisum sativum), after 4 days of flooding, it was found that the abscisic acid (ABA) level increased in the roots, causing complete closure of stomata, with enhanced ABA concentrations in the leaves (Zhang and Davies, 1987).

At 50 days after onset of the treatments, the leaves of the 8-day-waterlogged plants had significantly lower chlorophyll contents $(P \leq 0.05)$, registered as an SPAD index (measured

Table 6. Values of general symptoms of cape gooseberry (Physalis peruviana L.) subjected at an age of 2 months to waterlogging of different durations.

\begin{tabular}{ccccccc}
\hline \multirow{2}{*}{$\begin{array}{c}\text { Duration of } \\
\text { waterlogging (days) }\end{array}$} & \multicolumn{5}{c}{ Symptom scale values } \\
\cline { 2 - 7 } & $\mathbf{1 5}$ & $\mathbf{2 2}$ & $\mathbf{2 9}$ & $\mathbf{3 6}$ & $\mathbf{4 3}$ & $\mathbf{5 0}$ \\
\hline 0 & 5 & 5 & 5 & 5 & 5 & 5 \\
\hline 2 & 5 & 5 & 5 & 5 & 5 & 5 \\
4 & 3 & 4 & 4 & 4 & 5 & 5 \\
6 & 2 & 3 & 3 & 3 & 2 & 2 \\
8 & 2 & 2 & 2 & 2 & 2 & 1 \\
\hline
\end{tabular}

$0=$ dead plant, $1=75-100 \%$ of leaves completely curled throughout the plant, $2=75-100 \%$ of leaves curling without their margins connecting in the entire plant, 3 = leaf turgor loss from the base to the middle of the plant and leaves with curling upwards from the middle of the plant to the apex, $4=$ loss of leaf turgor from the base to the middle of the plant, $5=$ green plant without signs of stress.

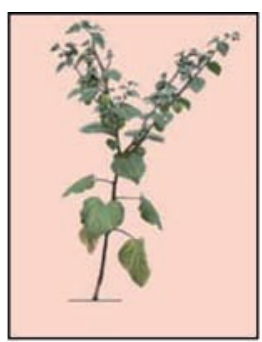

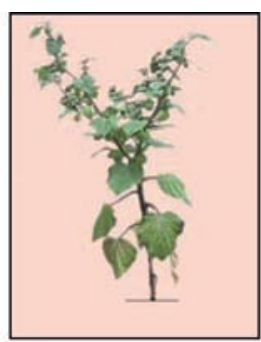

2

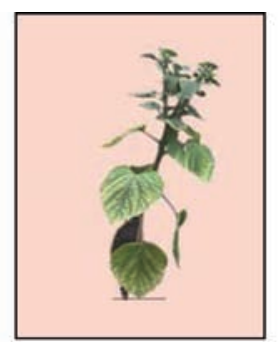

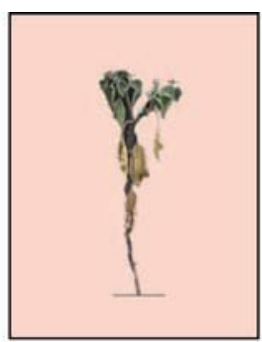

6

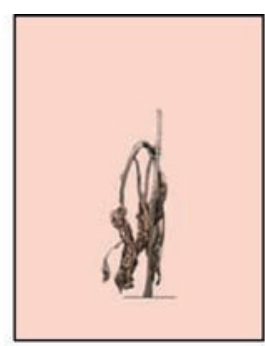

8 days

Figure 1. Appearance of cape gooseberry (Physalis peruviana L.) plants subjected at an age of 2 months to different durations (0 (control), 2, 4, 6 and 8 days) of waterlogging at 50 days after the treatments started. 
with a Minolta SPAD 502) of 17.48, as compared with the control (35.85); this drastic drop in the chlorophyll content began at day 29 (data not shown). The older leaves senesced prematurely (Figure 1) because of the reallocation of phloemmobile elements ( $\mathrm{N}, \mathrm{P}$, and $\mathrm{K}$ ) to younger leaves (Kläring and Zude, 2009), while the reduced permeability of the roots to water led to a decline in the leaf water potential and wilting (Dwivedi and Dwivedi, 2012). Additionally, in the 6- and 8-day-waterlogged plants, the leaf yellowing resulted from poisoning due to toxic substances (e.g. nitrites and sulphides) moving up from the dying roots (Ezin et al., 2008). These substances might be evacuated from dying cells or formed by microorganisms on the roots or in the soil (Dwivedi and Dwivedi, 2012). Generally, an excess of water, in quantity and time, can cause lethal conditions for roots, taking into consideration that plants, as aerobic organisms, require oxygen availability in the rhizosphere for nutrient uptake (Iacona et al., 2012).

The plants waterlogged for 8 days showed the first necrotic leaves in the basal part, from $15 \mathrm{~d}$ after the onset of the treatment, which affected the entire plants on day 43 (Figure 1).

\section{Conclusions}

The most severe reductions in growth and morphological variables were seen in the plants subjected to continuous waterlogging for 6 and 8 days and it was observed that these differences from the control plants began at 15 days after the treatments were initiated and the negative effects intensified as time passed.

Under the conditions of the experiment, the cape gooseberry easily resisted 2 days of waterlogging, but 4 days under these conditions slowed growth (biomass) and development, which led to a lower induction of floral organs and fruits over time.

The plants can withstand a waterlogging of 4 days with respect to height, leaf area and observed stress symptoms.

The severest stress symptoms of the 8-day-waterlogged plants, with marked reductions in root growth and death of the plants, can be supposed to be the result of hypoxic conditions in the rhizosphere and the consequent production of ethylene and abscisic acid, as well as the reduction of the photosynthetic rate.

These results are the first to be reported for waterlogging in cape gooseberry plants in Colombia, where the terrain is highly affected by global climate change.

\section{References}

Agudelo, O. 2009. Inundaciones en Colombia: un desastre que no es natural. UN Periódico 121, p. 18-19.

Angulo, R. (ed.). 2005. Uchuva. El cultivo. Universidad de Bogotá Jorge Tadeo Lozano, Bogotá.
Armstrong, W., R. Brändle \& M.B. Jackson. 1994. Mechanisms of flood tolerance in plants. Acta Bot. Neerl. 43, 307-358.

Armstrong, W. \& M.C. Drew. 2002. Root growth and metabolism under oxygen deficiency. pp. 729-761. In: Waisel, Y., A. Eshel, and U. Kafkafi (eds.). Plant roots. The hidden half. $3^{\text {th }}$ ed. Marcel Dekker, New York, NY.

Ashraf, M.A. 2012. Waterlogging stress in plants: A review. Afr. J. Agr. Res. 7, 1976-1981.

Bailey-Serres, J. \& L.A. Voesenek. 2008. Flooding stress: Acclimations and genetic diversity. Annu. Rev. Plant Biol. 59, 313-339.

Bange, M.P., S.P. Milroy \& P. Thongbai. 2004. Growth and yield of cotton in response to waterlogging. Field Crops Res. 88, 129-142.

Bennet, J. 2003. Opportunities for increasing water productivity of CGIAR crops through plant breeding and molecular biology. pp. 103-126. In: Kijne, J.W., R. Barker, and D. Molden (eds.). Water productivity in agriculture: limits and opportunities for improvement. CABI Publishing, Wallingford, UK.

Blom, C.W.P.M. \& L.A.C.J. Voesenek. 1996. Flooding: the survival strategies of plants. Tree 11, 290-295.

Bradford, K.J. \& S.F. Yang. 1981. Physiological responses of plants to waterlogging. HortScience 16, 25-30.

Casierra-Posada, F. \& N.E. Gómez. 2008. Crecimiento foliar y radical en plantas de fique (Furcraea castilla y F. macrophylla) bajo estrés por encharcamiento. Agron. Colomb. 26, 381-388.

Casierra-Posada, F. \& Y.A. Vargas. 2007. Crecimiento y producción de fruta en cultivares de fresa (Fragaria sp.) afectados por encharcamiento. Rev. Colomb. Cienc. Hortic. 1, 21-32.

Das, H.P. 2012. Agrometeorology in extreme events and natural disasters. BS Publikations, Hyderabad, India.

Dwivedi, P. \& R.S. Dwivedi. 2012. Physiology of abiotic stress in plants. Agrobios, Jodhpur, India.

Davies, F.S. \& J.A. Flore. 1986. Short-term flooding effects on gas exchange and quantum yield of rabbiteye blueberry (Vaccinium ashei Reade). Plant Physiol. 81, 289-292.

Ezin, V., R. de la Pena \& A. Ahanchede. 2010. Flooding tolerance of tomato genotypes during vegetative and reproductive stages. Braz. J. Plant Physiol. 22, 131-142.

Fischer, G. 2000. Crecimiento y desarrollo. pp. 9-26. In: Fischer, G., V.J. Florez, and A.D. Sora (eds.). Producción, poscosecha y exportación de la uchuva (Physalis peruviana L.) en Colombia. Unibiblos, Universidad Nacional de Colombia, Bogotá.

Fischer, G., G. Ebert \& P. Lüdders. 2007. Production, seeds and carbohydrate contents of cape gooseberry (Physalis peruviana L.) fruits grown at two contrasting Colombian altitudes. J. Appl. Bot. Food Qual. 81, 29-35.

Fischer, G. \& D. Miranda. 2012. Uchuva (Physalis peruviana L.). pp. 851-873. In: Fischer, G. (ed.). Manual para el cultivo de frutales en el trópico. Produmedios, Bogotá. 
Galindo, J.R. \& L.M. Pardo. 2010. Uchuva (Physalis peruviana L). Producción y manejo poscosecha. Produmedios, Bogotá.

Gibbs, J. \& H. Greenway. 2003. Mechanisms of anoxia tolerance in plants. I. Growth, survival and anaerobic catabolism. Funct. Plant Biol. 30, 1-47.

Hodgson, A.S. \& K.Y. Chan. 1982. The effect of short term waterlogging during furrow irrigation of cotton in a cracking grey clay. Aust. J. Agr. Res. 33, 109-116.

Iacona, C., M. Cirilli, A. Zega, E. Frioni, C. Silvestri \& R. Muleo. 2013. A somaclonal myrobalan rootstock increases waterlogging tolerance to peach cultivar in controlled conditions. Sci. Hortic. 156, 1-8.

Jackson, M.B. 1990. Hormones and developmental change in plants subjected to submergence or soil waterlogging. Aquatic. Bot. 38, 49-72.

Jackson, M.B. \& T.D. Colmer. 2005. Response and adaptations by plants to flooding stress. Ann. Bot. 96, 501-505.

Jordán, M. \& J. Casaretto. 2006. Hormonas y reguladores del crecimiento: etileno, ácido abscísico, brasinoesteroides, poliaminas, ácido salicílico y ácido jasmónico. In: Squeo, F.A. and L. Cardemil (eds.). Fisiología vegetal. Ediciones Universidad de La Serena, La Serena, Chile.

Kläring, H.-P. \& M. Zude. 2009. Sensing of tomato plant response to hypoxia in the root environment. Sci. Hortic. 122, 17-25.

Kozlowski, T.T. \& S.G. Pallardy. 1997. Physiology of woody plants. Academic Press, San Diego, CA.

Martínez-Alcántara, B., S. Jover, A. Quiñones, M.A. FornerGiner, J. Rodríguez-Gamir, F. Legaz, E. Primo-Millo \& D.J. Iglesias. 2012. Flooding affects uptake and distribution of carbon and nitrogen in citrus seedlings. J. Plant Physiol. 169, 1150-1157.

Martínez, F.E., J. Sarmiento, G. Fischer \& F. Jiménez. 2009. Síntomas de deficiencia de macronutrientes y boro en plantas de uchuva (Physalis peruviana L.). Agron. Colomb. 27, 169-178.
Larcher, W. 2003. Physiological plant ecology. Springer-Verlag, Berlin.

Lopez, M.V. \& D.A. del Rosario. 1983. Performance of tomatoes under waterlogged conditions. Philippine J. Crop Sci. 8, 75-80.

Lorbiecke, R. \& M. Sauter. 1999. Adventitious root growth and cell-cycle induction in deepwater rice, Plant Physiol. 119, 21-29.

Shiu, O.Y, J.H. Oetiker, W.K. Yip \& S.F. Yang. 1998. The promoter of LE-ACS7, an early flooding-induced 1-aminocyclopropane-1-carboxylate synthase gene of the tomato, is tagged by a Sol3 transposon. Proc. Natl. Acad. Sci. USA 95, 10334-10339.

Smit, B., M. Stachowiak \& E. Van Volkenburgh. 1989. Cellular processes limiting leaf growth in plants under hypoxic root stress. J. Exp. Bot. 40, 89-94.

Tadeo, F.R. \& A. Gómez-Cadenas. 2008. Fisiología de las plantas y el estrés. pp. 577-597. In: Azcón-Bieto, J. and M. Talón (eds.). Fundamentos de fisiología vegetal. McGraw-Hill Interamericana, Madrid.

Taiz, L. \& E. Zeiger. 2010. Plant physiology. $5^{\text {th }}$ ed. Sinauer Associates Inc., Sunderland, MA.

Villareal, A.d.P. 2014. Evaluación fisiológica de plantas de uchuva (Physalis peruviana L.), en la respuesta al estrés por anegamiento e infección de Fusarium oxysporum. M.Sc. thesis. Facultad de Ciencias Agrarias, Universidad Nacional de Colombia, Bogota.

Walter, S., H. Heuberger \& W.S. Schnitzler. 2004. Sensibility of different vegetables of oxygen deficiency and aeration with $\mathrm{H}_{2} \mathrm{O}_{2}$ in the rhizosphere. Acta Hort. 659, 499-508.

Yeboah, M.A., C. Xuehao, C.R. Feng, M. Alfandi, G. Liang \& M. Gu. 2008. Mapping quantitative trait loci for waterlogging tolerance in cucumber using SRAP and ISSR markers. Biotech. 7, 157-167.

Zhang, J. \& W.J. Davies. 1987. ABA in roots and leaves of flooded pea plants. J. Exp. Bot. 38, 649-659. 